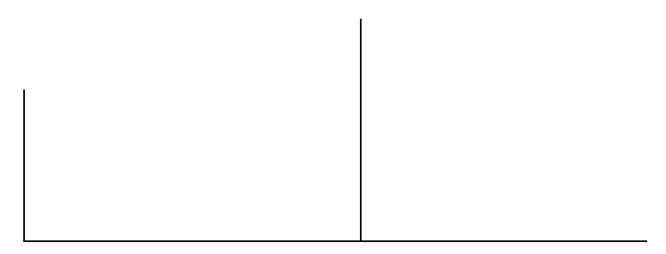

Rev. Latinoam. Psicopat. Fund., II, 4, 176-179

Homeopatia e psicanálise - clínica do semelhante e clínica da palavra

Durval Checchinato

Campinas, Papirus

1999

\title{
A quimera de uma outra medicina
}

\section{Rogério Pires}

\begin{abstract}
A homeopatia tem se apresentado ao mundo como um fenômeno estranho. Por expressar uma verdade empírica ela foi oficializada como especialidade médica. Mas suas bases e fundamentos não respeitam a lógica das convenções científicas nem se afirmam com força de saber. A homeopatia acaba sendo uma espécie de sistema terapêutico auto-referido, uma prática de cura legitimada apenas na experiência. Não existe uma teoria homeopática, rigorosa e consistente, amalgamada à vivência clínica. Este fato atravessa e se impõe em qualquer tentativa de pensar a homeopatia. É aí, numa radical imprecisão epistemológica, que reside a complexidade das reflexões sobre este tema.

Mas os homeopatas - presos à linearidade de pensamento, cheios de dogmas e simplificações - mal se dão conta desse problema. As escassas tentativas de discutir a homeopatia num contexto contemporâneo, incluindo novas perspectivas, são rechaçadas, percebidas como incômodas ou desnecessárias. Tudo é calmo e faz sentido na fabulação homeopática. Não há conflito, problema, nem urgência de pesquisas; o que há é a repetição incessante de um discurso esvaziado e conspiratório, é a crença numa batalha imaginária,
\end{abstract}


é a existência proclamada pela negação e o confronto. Colocando-se ilusoriamente num campo de oposição à medicina, alguns homeopatas transformam sua marginalidade em ideologia, incorrendo em negligências e imperícias.

Neste terreno pantanoso - feito de incertezas, equívocos e imprecisões - Durval Checchinato insere seu olhar e lança luz sobre os problemas. Sempre crítico em suas análises, o autor desde logo mostra que sua causticidade é o deslocamento de uma relação apaixonada: destrutivo com o discurso homeopático e suas estéreis variações, Durval é amável e generoso com a homeopatia. Sabedor dos benefícios desta prática, ele é veemente em seu inconformismo: como os homeopatas podem afirmar certas coisas ou crer em outras tão distantes daquelas enunciadas pelo fundador? A partir da constatação deste descompasso o autor empreende uma releitura das proposições da homeopatia, fazendo-as dialogar com os conceitos da psicanálise, num retorno a Hahnemann e às fontes originais.

É nessa volta às origens, nessa viagem retrospectiva, que Durval constrói a arqueologia de seu texto. Para ele, a problematização da homeopatia e a renitente crise em que ela está metida são conseqüências da incompreensão perpetrada por adeptos e praticantes. Para além das deformações discursivas, Durval encontra uma homeopatia coerente e científica, dona de uma episteme própria e definida, que possui vida na prática clínica, diferenças marcantes com a chamada alopatia e consonâncias com a teoria psicanalítica. A tese é a um só tempo audaciosa e controversa; a idéia prenunciada de que a homeopatia poderia caracterizar uma outra medicina é polêmica e até mesmo perigosa.

A homeopatia trata de sujeitos com demandas clínicas no corpo, portadores de doenças que exigem diagnósticos, intervenções e encaminhamentos. Praticar a homeopatia divorciada das especialidades da medicina contemporânea é uma temeridade inaceitável. Embora aborde este tema de forma crítica, o livro pode parecer, por vezes, tênue em seus alertas quanto aos limites da homeopatia e exageradamente entusiasta em relação às suas potencialidades. O problema proposto é de extrema complexidade com diversos desdobramentos, concernentes não só à homeopatia, mas a toda medicina.

A homeopatia resgata a escuta do sujeito e sua singularidade, concebe as interações mente-corpo como partícipes da saúde e da doença, e propõe uma observação e um acompanhamento menos intervencionistas e mais expectantes, respeitando uma temporalidade processual e não um apelo performático ou imediatista. Tudo isto pode ser muito bom e representar de fato uma contribuição à medicina. $\mathrm{O}$ problema reside fundamentalmente em dois tópicos: de um lado, a homeopatia possui muito mais uma intuição sobre o psíquico, o afetivo e o emocional do que uma construção teórica capaz de abarcá-los. Seus conceitos são precários e sua técnica - a consulta, a anamnese, a valorização dos sintomas psíquicos soa postiça e artificial. De outro, não é mais possível perpetuar um discurso 
R $\quad E \quad V \quad$ I $S$ S $T$ T

LATINOAMERICANA

DE PSICOPATOLOGIA

FUNDAMENTA L

romântico e ingênuo, demonizando a alopatia, a indústria farmacêutica e as novas tecnologias.

A própria discussão sobre os danos e os benefícios da abordagem médica contemporânea redunda inócua nesse caso. A medicina, apoiada num aparato técnico cada dia mais sofisticado, dita as regras das intervenções no corpo, submetendo o médico e sua sensibilidade clínica. As fronteiras entre tecnologia e medicina são a todo instante transpassadas, transformando aquilo que já foi chamado de "arte de curar" num conjunto de artifícios técnicos e normas protocolares. Nenhum médico deixará de fazer uma biópsia frente à mais remota chance de malignidade de um tecido. Nenhum oncologista usará os quimioterápicos surgidos há poucos anos se no último congresso foi divulgada uma nova droga que oferece mínimos benefícios em relação às anteriores, mesmo que os custos materiais sejam significativamente maiores.

Por paradoxal que possa parecer, não há lugar para a racionalidade na medicina contemporânea. O médico perdeu sua capacidade de crítica e seu discernimento; cada vez mais as condutas são dadas por parâmetros de controle estatísticos, estudos de acurácia descontextualizados da história subjetiva do sujeito. Mas a homeopatia não é de fato a resposta aos descaminhos da técnica nem o resgate dos valores de uma arte de outrora. Nenhum homeopata, conseqüente em sua prática, deixará de recorrer aos mesmos procedimentos e recursos disponíveis à medicina contemporânea. As críticas aos avanços tecnológicos e suas implicações são suplantadas pelos inegáveis benefícios: diagnósticos podem ser feitos com mais segurança e precocidade, vários esquemas terapêuticos são de fato exitosos em doenças até então de prognósticos reservados. Essa realidade alimenta a marcha inexorável do desenvolvimento.

E aí surge o impasse: a homeopatia é uma prática generalista, cuja especificidade está na escuta do sujeito e não na cura dos sintomas. Mais próxima da psicanálise do que da medicina, a homeopatia enfrenta seu dilema: como tratar os doentes no universo fragmentário da tecnologia médica e suas especializações? E mais: como desenvolver seu modelo a partir do inusitado pressuposto de que um remédio que não possui matéria, administrado ao corpo físico, produz efeitos que podem atingir a dimensão psíquica? De que ordem de "remédio" os homeopatas estão falando?

Durval não aborda o mistério da ação do semelhante, mas salienta os contornos da episteme homeopática, alertando que só dentro dela o homeopata reconhece os seus limites e corre o próprio risco. Ele fala dos encaminhamentos precisos daquele que domina seu conhecimento; aquele que nem arroga uma auto-suficiência danosa e irresponsável nem se acovarda no momento de vivenciar a plenitude de sua ciência.

Mas o desdobramento imediato dessa fala é um problema epistemológico de improvável solução, um beco sem saída que o livro apenas tangencia: o homeopata 
é médico, e não terapeuta ou psicanalista. O reconhecimento dos limites da episteme homeopática não basta para o pleno exercício dessa profissão. Talvez um psicanalista que ouça de seu paciente uma recorrente queixa de dor epigástrica possa permanecer no seu campo de escuta, restrito às associações do paciente e à sua própria atenção flutuante. Talvez ainda ele se outorgue o direito de usar a sua sensibilidade para, dentro do contexto em que se encontra com o paciente, sugerir a visita a um médico. Mas se o analista se abstiver, e a queixa se revelar uma grave úlcera de estômago, isto não implica responsabilidade médica ao psicanalista.

Entretanto, uma semelhante montagem referida ao consultório de um homeopata seria uma negligência, uma irresponsabilidade ou um erro diagnóstico. $\mathrm{E}$ assim ocorre com todas as queixas físicas (e mesmo as psíquicas), que devem ser primeiro referendadas pelo raciocínio médico e só depois avaliadas no contexto da "episteme homeopática". Por isso a tendência que se vislumbra não é a de que a homeopatia se transforme num forte contraponto à medicina contemporânea, mas, ao contrário, que progressivamente se confirme uma crescente subordinação à técnica e ao enfoque especializado. A lógica da medicina sugere que não há mais lugar para o médico homeopata, "purista" e alternativo, tal como o concebíamos há algum tempo; sugere ainda que cada vez mais a homeopatia será um conhecimento complementar, coadjuvante e dependente.

Mas o futuro não é dado e as projeções muitas vezes não se cumprem. Ao leitor deste livro de Durval Checchinato fica frisada a conviç̧ão na homeopatia e a crítica ao reducionismo da medicina contemporânea. O texto aponta, sem maniqueísmos, que a saúde e a doença podem ser abordadas para além da hegemonia de uma lógica. A narrativa faz pensar nos caminhos de uma nova medicina, engendrada na esquecida sensibilidade clínica: homeopatas integrados à medicina e médicos abertos à homeopatia. Este é o prazer do livro: superar a atmosfera de vazio e ceticismo sem medo de parecer romântico - como um convite ao sonho, como a expressão compartilhada de um desejo. 